\author{
Krzysztof WILDE ${ }^{1}$ \\ Kazimierz JAMROZ \\ Dawid BRUSKI ${ }^{3}$ \\ Stanisław BURZYŃSKI ${ }^{4}$ \\ Jacek CHRÓŚCIELEWSKI ${ }^{5}$ \\ Wojciech WITKOWSKI ${ }^{6}$
}

\title{
BADANIA NUMERYCZNE ZDERZENIA AUTOBUSU W UKŁADZIE BARIERA I KRATOWNICOWA KONSTRUKCJA WSPORCZA
}

\begin{abstract}
Zdarzenia spowodowane wypadnięciem pojazdu z trasy stanowią 20 - $30 \%$ ogółu zdarzeń niebezpiecznych na drogach. Najczęściej występującymi przeszkodami i niebezpiecznymi obiektami przy drodze, w które uderza wypadający z niej pojazd są: bariery na autostradach i drogach ekspresowych oraz drzewa, słupy i znaki drogowe na innych szlakach. Do opracowania metody projektowania, tj. doboru lokalizacji i rodzaju urządzeń bezpieczeństwa ruchu, potrzebne są badania poligonowe i symulacyjne funkcjonowania tych urządzeń w chwili uderzenia pojazdu. $\mathrm{W}$ pracy przedstawione zostały przykłady zastosowania badań numerycznych do symulacji pracy układu bariera drogowa i konstrukcja wsporcza znaku drogowego w przypadku uderzenia w nie autobusu.
\end{abstract}

Słowa kluczowe: urządzenia BRD, badania numeryczne, zderzenia pojazdów, otoczenie drogi, Metoda Elementów Skończonych

\section{Wstęp}

Wypadki drogowe są nadal jedną z przyczyn tragedii wielu polskich rodzin. Duży udział w tym mają zdarzenia niebezpieczne spowodowane wypadnięciem pojazdu z trasy, skutkiem których są wtórne wypadki kończące się wywróceniem pojazdu lub uderzeniem pojazdu w obiekt znajdujący się $w$ otoczeniu dro-

\footnotetext{
${ }^{1}$ Autor do korespondencji/corresponding author: Krzysztof Wilde, Politechnika Gdańska, ul. Narutowicza 11/12 80-233 Gdańsk, +48583471891, krzysztof.wilde@ wilis.pg.gda.pl

${ }^{2}$ Kazimierz Jamroz, Politechnika Gdańska

${ }^{3}$ Stanisław Burzyński, Politechnika Gdańska

${ }^{4}$ Dawid Bruski, Politechnika Gdańska

${ }^{5}$ Jacek Chróścielewski, Politechnika Gdańska

${ }^{6}$ Wojciech Witkowski, Politechnika Gdańska
} 
gi. Mimo że w ostatnich dziesięciu latach nastąpił istotny postęp w zmniejszaniu liczby tych zagrożeń, to wciągu ostatnich 25 lat na polskich drogach zginęło ponad 20 tysięcy osób w wypadkach związanych z wypadnięciem pojazdu z jezdni (z tego zdecydowana większość w wyniku uderzenia pojazdu w drzewo) [1].

Wypadki związane $\mathrm{z}$ wypadnięciem pojazdu z trasy charakteryzują się zazwyczaj bardzo ciężkimi następstwami, gdyż często kończą silnym uderzenie pojazdu w przeszkodę trwałą (drzewo, słup, podpora obiektu mostowego, czoło przepustu, bariera). Szczególnie duże zagrożenie w Polsce występuje na drogach położonych w północnej części kraju, gdzie wzdłuż dróg pozostało wiele historycznych alei drzew. Do najbardziej drastycznych przykładów należy wypadek najechania na drzewo przepełnionego autobusu pod Gdańskiem w roku 1994, w którym śmierć poniosły 32 osoby, a ponad 40 zostało rannych.

Dotychczas znaczną liczbę badań przeprowadzono pod kątem określenia zależności pomiędzy intensywnością ruchu i geometrią drogi a wypadkami drogowymi. Badania te wykazały, że ulepszenia konstrukcji geometrii jezdni może znacząco zmniejszyć liczbę i skutki wypadków. Znacznie mniej prac poświęcono rozpoznaniu wpływu odpowiednich czynników na zdarzenia wypadnięcia pojazdu z drogi i ich skutków. Badania statystyczne wypadków drogowych prowadzone w wielu krajach wskazują, że około jedna trzecia ofiar śmiertelnych jest następstwem wypadnięcia pojazdu z trasy [2].

Pod pojęciem „wypadnięcie z drogi” rozumie się takie pierwotne zdarzenie drogowe, w którym pojazd opuszcza jezdnię w wyniku utraty stateczności lub nagłej zmiany kierunku jazdy (wymuszonej jazdą ze zbyt dużą prędkością, utratą przyczepności koła do nawierzchni itp.). Po wystąpieniu tego typu zjawisk niekiedy następuje powrót pojazdu na jezdnię, ale bardzo często występuje wtórne zdarzenie niebezpieczne. Takie zdarzenia wtórne polegają na wywróceniu się pojazdu, wjechaniu do rowu, uderzeniu w skarpę lub uderzeniu w urządzenie, czy obiekt zlokalizowany w pasie drogowym albo jego bliskim otoczeniu, np. najechanie pojazdu na: barierę drogową, drzewo, słup lub znak drogowy [3].

Studium literatury wskazuje, że część badaczy poszukiwało zależności wpływu wybranych parametrów drogi (szerokość jezdni, rodzaj i szerokość pobocza) oraz usytuowania obiektów inżynierskich (mosty, przepusty, znaki drogowe), przeszkód przy drodze (drzewa, słupy), urządzeń drogowych (bariery drogowe i wygrodzenia), na zagrożenie wypadkami związanymi z wypadnięciem pojazdu z drogi. Wyniki tych badań wykorzystano do modelowania i symulowania wpływu różnych kombinacji parametrów geometrycznych drogi oraz parametrów ruchu na częstość i skutki wypadków. Na podstawie modeli opracowano zbiór działań prewencyjnych i wykazano, że częstotliwość zdarzeń można znacząco zmniejszyć poprzez [4]:

- zwiększenie szerokości pasa ruchu i szerokości pobocza,

- poszerzenie szerokości pasa dzielącego,

- poszerzenie szerokości jezdni przy dojeździe do obiektu mostowego, 
- przenoszenie i usuwanie niebezpiecznych obiektów drogowych,

- łagodzenie pochylenia stoków i skarp rowów,

- zastosowanie barier i innych systemów ochronnych.

Wykorzystując wyniki badań terenowych, modelowania matematycznego i symulacji komputerowych określono zalecane szerokości strefy wolnej od przeszkód oraz odległość od jezdni i wysokość barier drogowych [5]. Drzewo zbyt blisko jezdni, zła konstrukcja słupa lub znaku drogowego, nieprawidłowo zaprojektowany lub wybudowany system barier ochronnych są zagadnieniami będącymi przedmiotem studiów, badań i przygotowania norm, wytycznych, czy przykładów tzw. dobrej praktyki [6].

Drogowe bariery ochronne to jedne $\mathrm{z}$ ważniejszych czynnych urządzeń bezpieczeństwa ruchu drogowego tzn. takich, z którymi pojazd podczas wypadku wchodzi w bezpośredni kontakt. Dlatego każdego rodzaju bariera powinna być odpowiednio przystosowana do przejęcia ewentualnego uderzenia pojazdu. Do podstawowych celów barier ochronnych należą:

- zapobieganie niekontrolowanemu zjazdowi pojazdu z toru ruchu (drogi, jezdni) w miejscach, gdzie jest to niebezpieczne,

- ochrona życia i mienia uczestników ruchu i osób użytkujących tereny położone przy drodze.

Zadaniem bariery jest zapewnienie bezpieczeństwa wszystkim uczestnikom ruchu, tak aby ewentualne skutki wypadku były jak najmniejsze. Dodatkowo bariery z odblaskami wyznaczają krawędzie jezdni w warunkach nocnych lub przy ograniczonej warunkami atmosferycznymi widoczności (deszcz, śnieg, mgła). Ponadto bariery odgradzają drogę od terenów przyległych, innych tras lub ulic lokalnych. Podczas uderzenia pojazdu w system ochronny, urządzenie powinno stworzyć odpowiednie warunki zmniejszenia zagrożenia w przypadku zdarzenia niebezpiecznego, $\mathrm{tj}$.:

- opóźnienia działające na osoby w pojeździe nie powinny przekroczyć wartości bezpiecznych,

- pojazd powinien zostać wyprowadzony na tor ruchu równoległy do bariery,

- uszkodzenia pojazdu w miarę możliwości powinny być niewielkie.

Przy budowie dróg, projektanci systemów ochronnych powinni uwzględnić wszystkie miejsca zagrożenia. Pomocne są tu wytyczne stosowania barier ochronnych ujmujące najważniejsze aspekty ich projektowania [7]. Należy podkreślić, że od 2010 r. montowane systemy barier drogowych muszą być przebadane i posiadać certyfikat zgodności oraz deklarację właściwości użytkowych.

Drogowe i mostowe bariery ochronne, osłony energochłonne i pasywne konstrukcje wsporcze są urządzeniami bezpieczeństwa ruchu zmniejszającymi prawdopodobieństwo wystąpienia i skutki wypadnięcia pojazdu $\mathrm{z}$ drogi. $\mathrm{Z}$ racji dużego natężenia ruchu i znacznych prędkości pojazdów, drogi krajowe z zasady są wyposażane w tego typu urządzenia. Skalę i wagę zagadnienia podkreśla fakt, że drogi krajowe mają ok. 19 tys. km, na których występuje ok. 6,9 tys. obiektów mo- 
stowych o długości łącznej $367 \mathrm{~km}$, co daje prawie $2 \% \mathrm{z}$ całości tych tras. W prawdzie na obiektach mostowych ma miejsce, z punktu widzenia statystycznego, „tylko” ok. 0,5 \% ogółu wypadków drogowych, to jednak ich tzw. „ciężkość”, tj. zagrożenie życia, jest zdecydowanie większe niż na innych odcinkach dróg.

Funkcjonowanie i wymagania wobec barier drogowych i konstrukcji wsporczych regulują normy europejskie. W normach PN-EN 1317 zawarto wymagania dotyczące warunków, jakim powinny odpowiadać „,systemy ograniczające drogę” i badania, które należy przeprowadzone, aby dopuścić je do stosowania [8]. Normy te definiują klasy działania barier ochronnych poprzez określenie ich cech funkcjonalnych, takich jak poziom powstrzymywania, deformację bariery oraz oddziaływanie dynamiczne na pasażerów pojazdu. Cechy te są ustalane na podstawie tzw. testów zderzeniowych. Przy czym klasy działania barier ochronnych zależą od prędkości, masy i kąta najechania pojazdu na barierę. Natomiast normy te nie wskazuje wymiarów, kształtu i materiału, z jakiego ma być wykonana bariera. Również nie wskazują, na jakich drogach, które z urządzeń BRD należy stosować. Te kwestie pozostają $w$ gestii krajowych administracji drogowych. Stąd w Polsce GDDKiA w 2010 r. opracowała, obowiązujące do dziś, wytyczne stosowania barier na sieci dróg krajowych [9]. Wytyczne te biorą pod uwagę występowanie zagrożeń, parametry ruchu, klasę drogi, a także zasady ustalania cech funkcjonalnych barier i sposób ich usytuowania. Podjęta w 2014 r. aktualizacja tych wytycznych nie znalazła uznania merytorycznego. Dlatego w 2015 r. stworzono dwa projekty badawcze, jako wspólne przedsięwzięcie NCBiR i GDDKiA, dotyczące urządzeń bezpieczeństwa ruchu drogowego, w tym drogowych barier ochronnych i drogowych urządzeń wsporczych. W zakresie badań przewidziano m.in. poligonie testy zderzeniowe i badania symulacyjne [10], [11], [12], [13], [14].

\section{Symulacje numeryczne zderzenia TB51}

Przedmiotem badań jest symulacja zderzenia autobusu z barierą mostową w miejscu usytuowania kratowej konstrukcji wsporczej dla tablicy informacyjnej nad pasem drogi. Parametry zadania spełniają warunki testu zderzeniowego TB51 [8]: prędkość zderzenia $70 \mathrm{~km} / \mathrm{h}$, kąt zderzenia $20^{\circ}$, całkowita masa pojazdu $13000 \mathrm{~kg}$. Układ pojazdu względem bariery przedstawiono na Rys. 1.

Badania numeryczne zrealizowane są w formalizmie Metody Elementów Skończonych (MES). Opis matematyczny bariery opracowany został przez autorów publikacji, zaś model autobusu zaczerpnięty ze strony http://ncac.gwu.edu/ (dostęp w dniu 1.03.2016). Jednak, ze względu na zauważone pewne nieprawidłowości w oryginalnym modelu autobusu, dokonano zmian polegających na wprowadzeniu korekty opisu zawieszenia pojazdu. Symulacje przeprowadzono za pomocą systemu LS-DYNA (wersja MPP double precision R8.1.0) [15]. Obliczenia prowadzono na superkomputerze „Tryton”, zarządzanym przez KDM TASK w Gdańsku. Każde z zadań było realizowane przy użyciu 384 wątków 
(16 szt. 24-rdzeniowych procesorów). Przykładowy czas obliczeń to 17h28' dla zadania bez wysięgnika.

Geometria bariery odpowiada barierze typu Orsta Stal A/S [11] o poziomie powstrzymywania H2 i szerokość współpracującej W2. Zestawienie liczby węzłów i elementów modelu matematycznego ujmuje Tabela 1. Do dyskretyzacji bariery wykorzystano elementy powłokowe ELFORM $=2$ (Belytschko-Tsay) oraz elementy objętościowe ELFORM $=2$, FI S/R Solid (nomenklatura wg dokumentacji programu LS-DYNA).

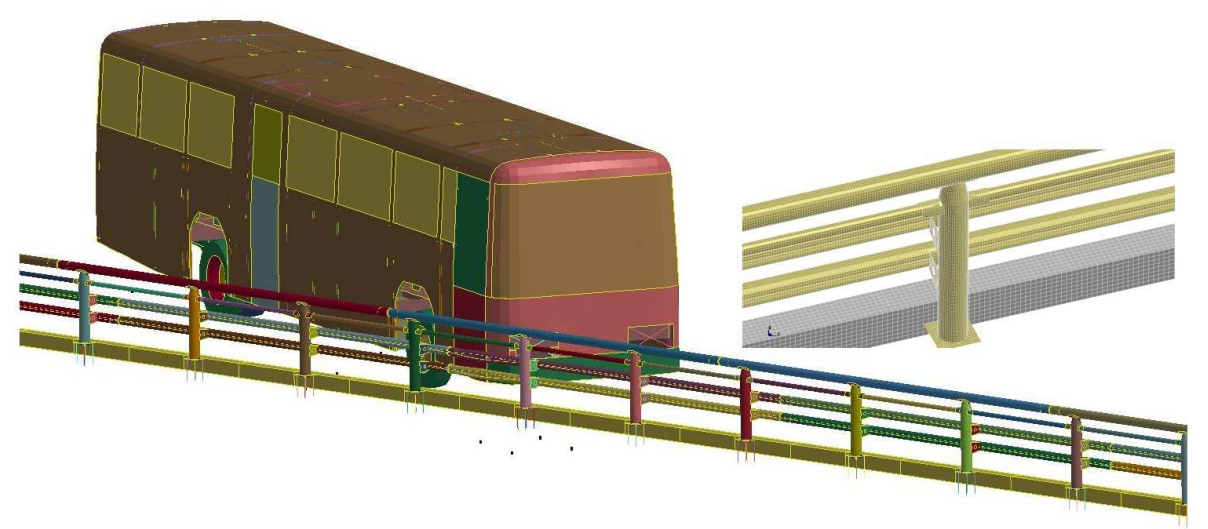

Rys. 1. Test TB51, widok ogólny, wizualizacja modelu numerycznego

Fig. 1. Test TB51, general view, visualization of the numerical model

Tabela 1. Parametry dyskretyzacji bariery ochronnej, wysięgnika i autobusu Table 1. Discretization parameters: road barrier, support structure and bus

\begin{tabular}{|c|c|c|c|}
\hline & Bariera & Wysięgnik & Autobus \\
\hline Węzły & 584850 & 15244 & 54480 \\
\hline Elementy skończone & 542648 & 18003 & 51322 \\
\hline
\end{tabular}

W obliczeniach uwzględniono nieliniowość fizyczną i materiałową. Całkowanie równania ruchu przeprowadzono metodą jawną (explicit). Początkowy krok całkowania (obliczony przez program) równy był $6,08 \times 10^{-7} \mathrm{~s}$. Kontrolę form pasożytniczych w elementach z całkowaniem zredukowanym prowadzono za pomocą techniki stiffness form of type 2, Flanagan-Belytschko zakładając wartość współczynnika dotyczącego form zero-energetycznych QH (hourglass coefficient) równą 0,03 .

Materiał krawężnika przyjęto jako MAT_001 (elastic) o gęstości $2450 \mathrm{~kg} / \mathrm{m}^{3}$, module Younga $36 \mathrm{GPa}$ i współczynniku Poissona 0,2. Materiał bariery (stale St355 oraz St235), przyjęto jako MAT_024 (piecewise_linear_plasticity) o gęstości $7850 \mathrm{~kg} / \mathrm{m}^{3}$, module Younga $210 \mathrm{GPa}$ i współczynniku Poissona 0,2. Początkowe granice plastyczności przyjęto odpowiednio, jako $355 \mathrm{MPa}$ i $235 \mathrm{MPa}$. Krzywe wzmocnienia stali [4] pokazano na Rys. 2. 


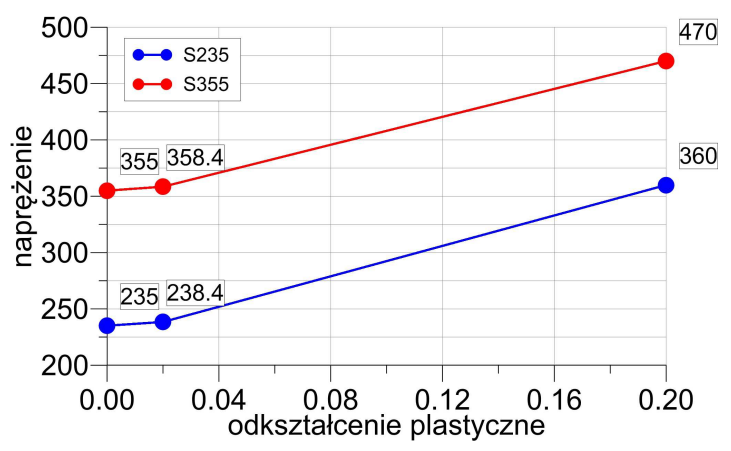

Rys. 2. Krzywe wzmocnienia stali, na podstawie [4]

Fig. 2. Steel hardening curves, based on [4]

W obliczeniach przyjęto szereg założeń upraszczających, wśród najistotniejszych należy wymienić brak kryterium zniszczenia łączników śrubowych i spawów w barierze.

Jako kontrolę poprawności wyników numerycznych prowadzono analizę bilansu energii kinetycznej, potencjalnej i całkowitej (Rys. 3). Należy zaznaczyć, że energia związana z kontrolą form pasożytniczych pozostawała prawidłowo na bardzo niskim poziomie, w stosunku do innych składników energii w trakcie całej ewolucji dynamicznego układu symulacji uderzenia autobusu o barierę ochronną.

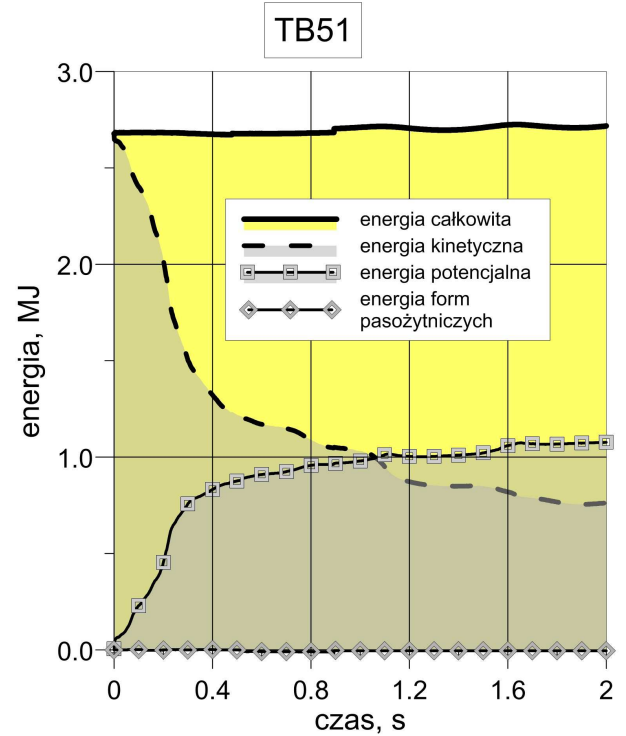

Rys. 3. Bilans energii w układzie dynamicznym w trakcie symulacji dla testu TB51

Fig. 3. Energy balance in a dynamic system during the simulation of test TB51 
Otrzymane wyniki obliczeń testu zderzeniowego autobusu $\mathrm{z}$ barierą ochronną porównano z wyselekcjonowanymi względem czasu rezultatami badań poligonowych. Na Rys. 4 przedstawione są trzy konfiguracje testu zderzeniowego: moment najazdu autobusu na barierę, kontakt przodu autobusu z barierą oraz moment odjazdu autobusu po zderzeniu.

Ocena jakościowa zgodności wyników symulacji i danych eksperymentalnych jest pozytywna. Symulacje poprawnie określiły maksymalne trwałe deformacje (przesunięcia maksymalne) bariery, które wyniosły $550 \mathrm{~mm}$. Całkowita długość odcinka bariery, na której wystąpiły deformacje plastyczne wyniosła $12 \mathrm{~m}$, zaś w teście poligonowym było to $11 \mathrm{~m}$. Tor ruchu autobusu także został poprawnie odwzorowany.
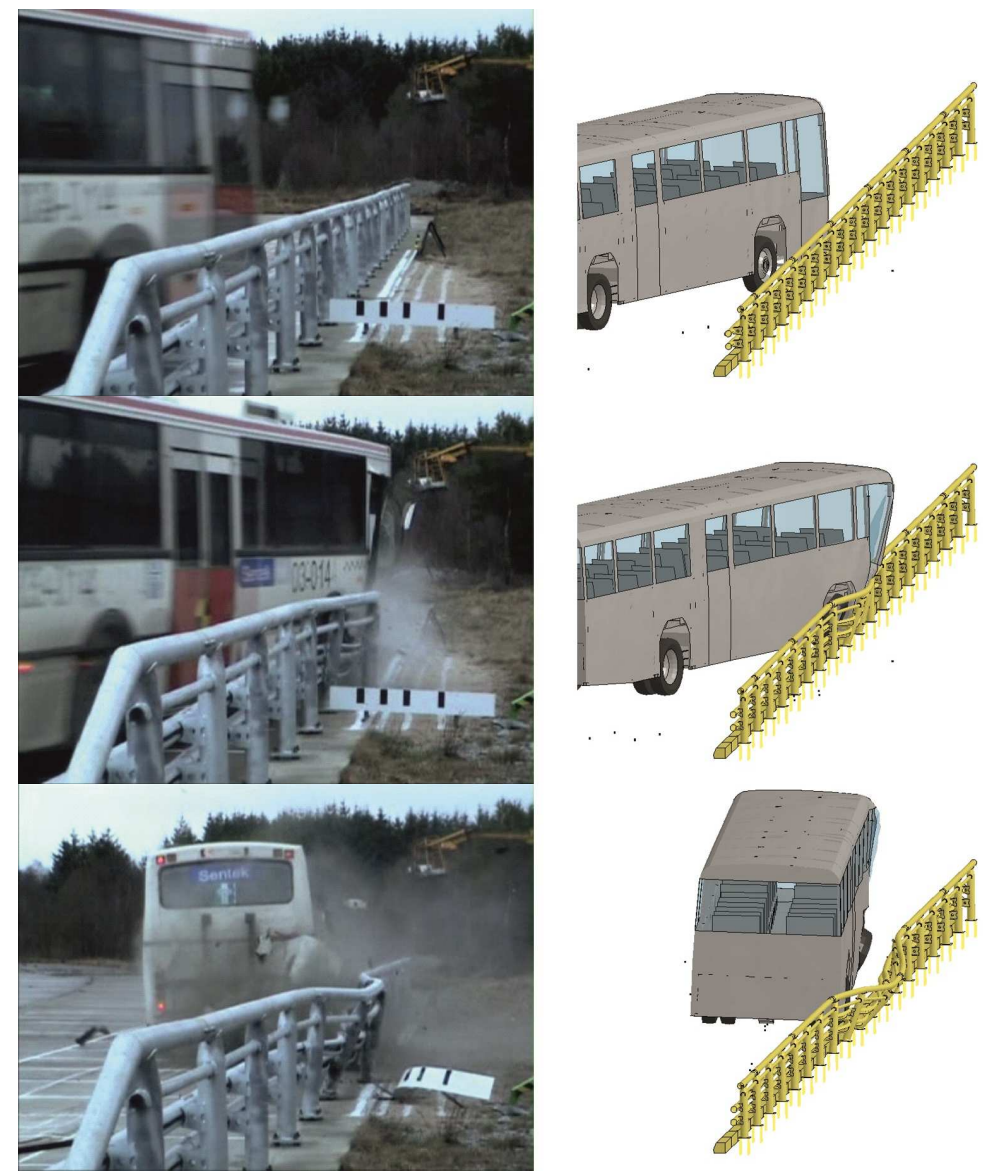

Rys. 4. Test TB51, porównanie zderzeniowego testu polowego i jego symulacji numerycznej

Fig. 4. Test TB51, comparision of experimental crash test and numerical simulation 


\section{Symulacje numeryczne zderzenia TB51 z barierą i wysięgnikiem}

W kolejnym etapie badań podjęto się oceny wpływu kratowej konstrukcji wsporczej pod tablice informacyjne usytuowanej za barierą w obszarze zasięgu potencjalnego uderzenia autobusu na przebieg jego zderzenia. Słup i ramię wysięgnika wykonane są z prętów okrągłych o przekroju pełnym ze stali S235. Fragment słupa znajdujący się $\mathrm{w}$ bezpośrednim sąsiedztwie bariery, a mogący wejść $\mathrm{z}$ nią $\mathrm{w}$ kontakt, został, dla celów obliczeniowych, wzbogacony o niekonstrukcyjną (niefizyczną) powłokę umożliwiającą symulację kontaktu. Powłoka ta nie ma sztywności ani masy. Siatka dyskretyzacyjna wysięgnika pokazana jest na Rys. 5.
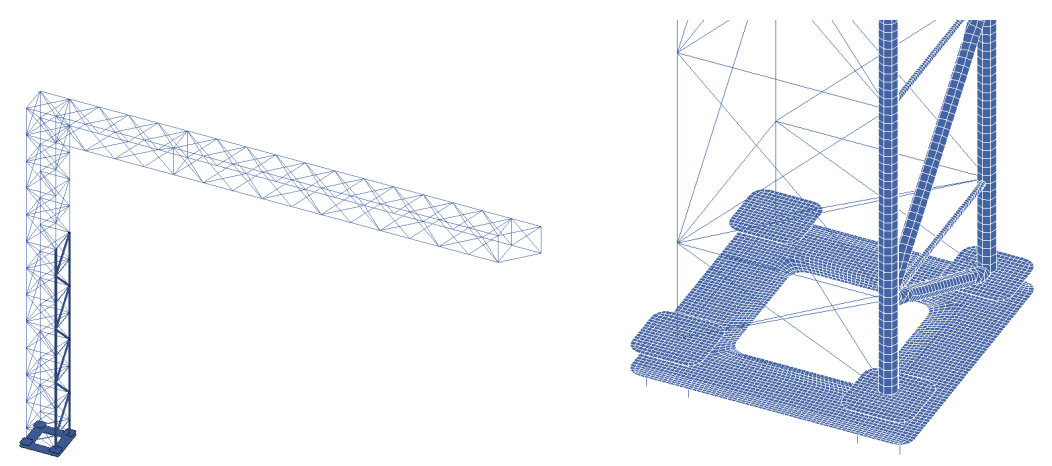

Rys. 5. Wysięgnik, wizualizacja ogólna oraz szczegół podstawy słupa

Fig. 5. Supporting structure, overall view and detail of a basis

Wyniki symulacji zderzenia autobusu $\mathrm{z}$ barierą oraz zderzenia $\mathrm{z}$ barierą i wysięgnikiem pokazano na rysunkach 6,7 i 8 . Zderzenie autobusu powoduje przemieszczenie się górnej części bariery. W przypadku systemu z wysięgnikiem, przemieszczający się przód auta zderza się także ze słupem wysięgnika (Rys. 7). Wysięgnik przejmuje cześć energii uderzenia znacząco zmniejszając trwałe przemieszczenie bariery. Porównanie deformacji barier dla obu rozpatrywanych przypadków pokazane jest na Rys. 8.

W przypadku zderzenia autobusu w układ bariera-wysięgnik następuje bezpośredni kontakt dachu autobusu i słupa wysięgnika. Trwałe przemieszczenie górnej części słupa wysięgnika wyniosło $200 \mathrm{~mm}$. Porównanie trwałych deformacji bariery oraz układu bariera i wysięgnik pokazane jest na Rys. 8. W przypadku zderzenia z wysięgnikiem trwałe deformacje słupków są znacząco mniejsze niż, gdy zderzenie następuje w samą barierę. Pokazane wyniki potwierdzają wcześniejszą uwagę dotyczącą dużej sztywności wysięgnika i jego znaczącego udziału w analizowanym zdarzeniu. 

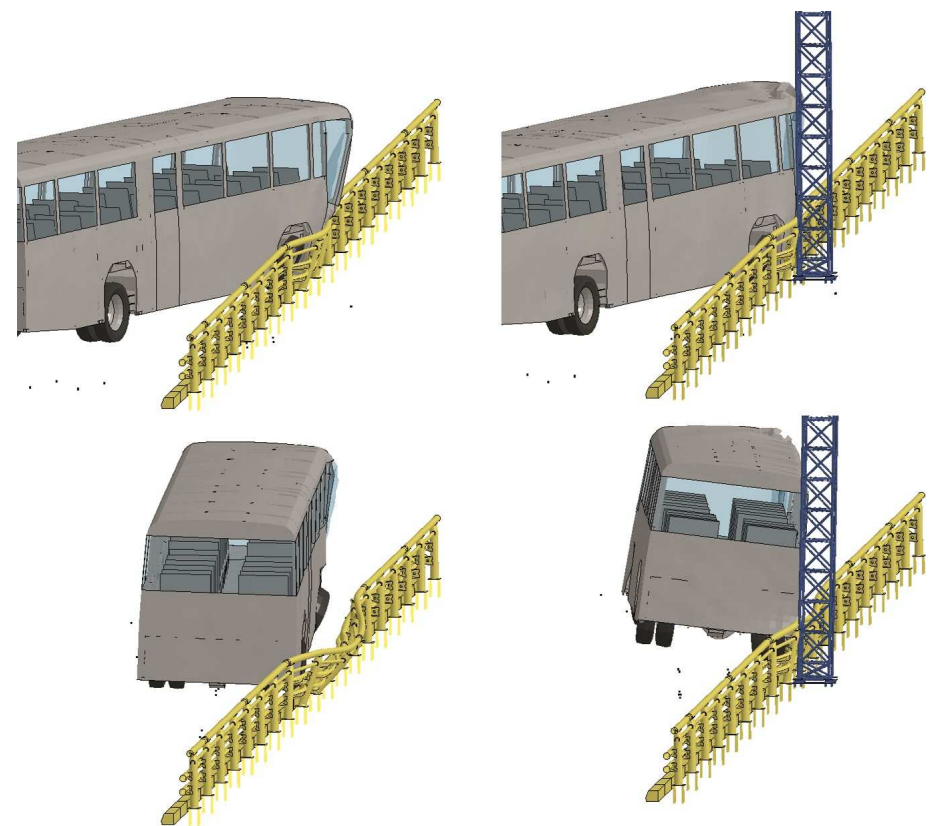

Rys. 6. Test TB51: lewa strona wyniki bez wysięgnika, prawa z wysięgnikiem

Fig. 6. Test TB51: Crash without and with supporting structure

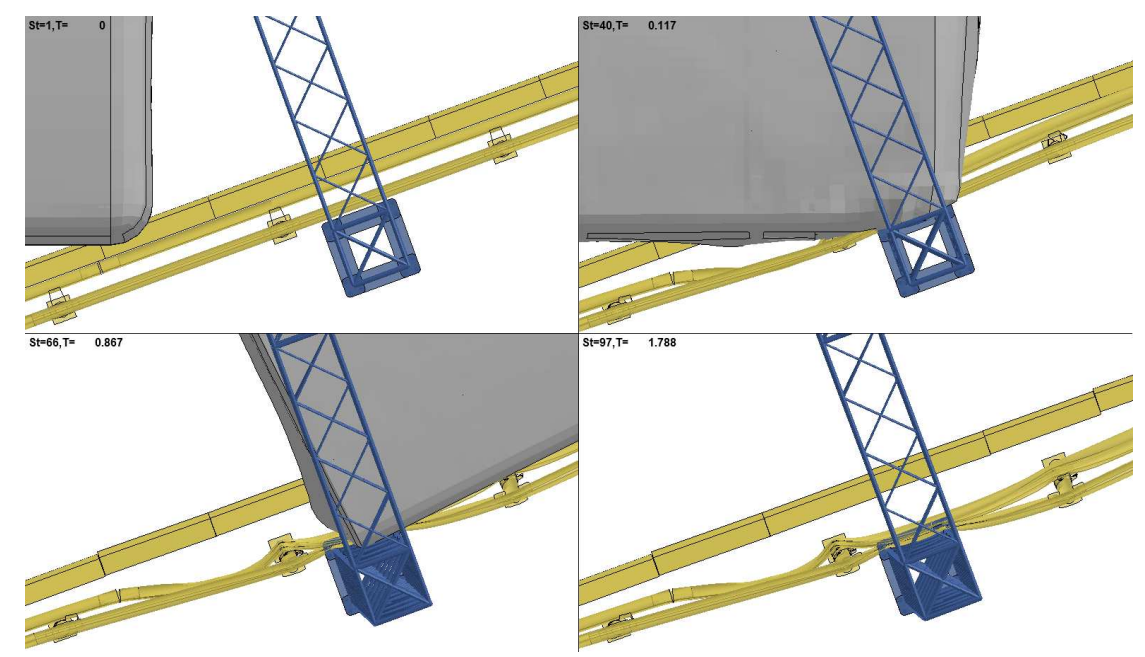

Rys. 7. Widok zdeformowanej bariery przy testach z wysięgnikiem

Fig. 7. Detailed view of deformed barrier in test with supporting structure 

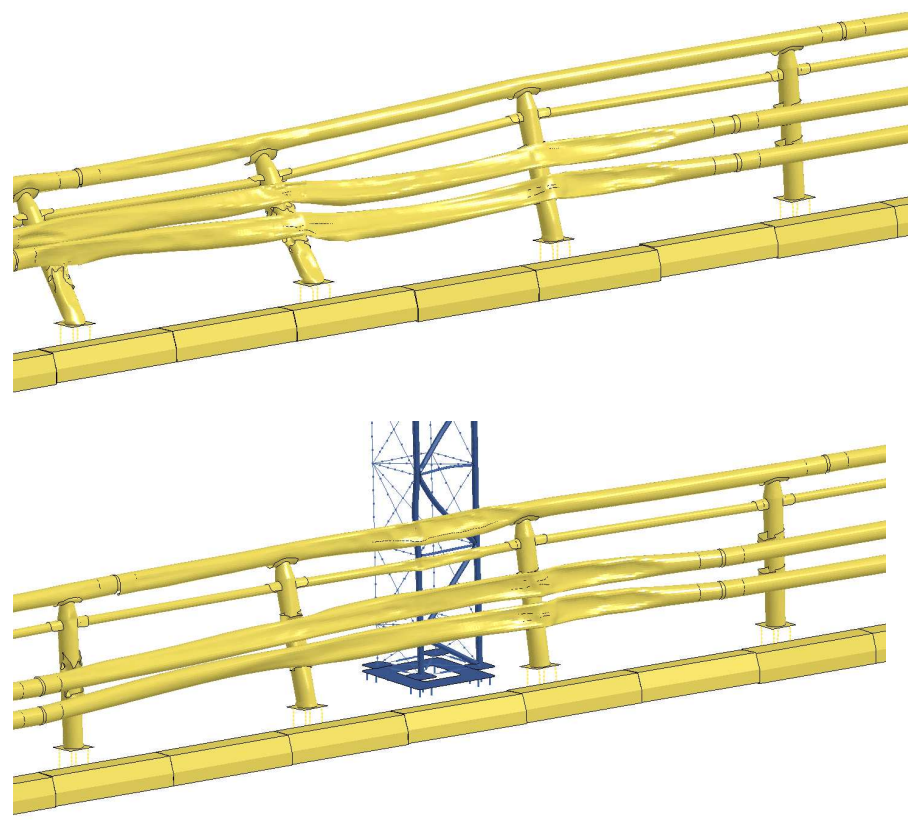

Rys. 8. Widok zdeformowanej bariery przy testach bez i z wysięgnikiem

Fig. 8. View of deformed barrier in test without and with supporting structure

W analizowanych przypadkach zderzeń autobusu porównane zostały przebiegi czasowe wskaźnika intensywności przyspieszenia ASI (Rys. 9), obliczone na podstawie przyspieszeń w akcelerometrze umieszczonym w pobliżu środka ciężkości pojazdu. Choć różnice w trwałych deformacjach samej bariery i bariery z wysięgnikiem są znacząco różne, to jednak przebiegi czasowe parametru ASI dla obu przypadków są podobne. Największa wartość parametru ASI dla zderzenia autobusu w samą barierą wyniosłą 1,58, a dla uderzenia w układ bariera i wysięgnik 1,77 . W przypadku uderzenia w barierę i wysięgnik maksymalna wartość parametru ASI związana jest z kontaktem autobusu zarówno $\mathrm{z}$ barierą jak i wysięgnikiem. Wzrost wskaźnika ASI dla przypadku bariery z wysięgnikiem wynosi $12 \%$. Maksymalna wartość ASI następuje w około 0,3 sekundzie zderzenia, co spowodowane jest przesunięciem momentu pełnego kontaktu autobusu z barierą i wysięgnikiem.

Poprawność zrealizowanych symulacji numerycznych potwierdzona została analizą zmienności energii związanych z procesem dynamicznym. Energia form pasożytniczych jest na bardzo niskim poziomie względem pozostałych tzw. energii fizycznych (Rys. 10). 


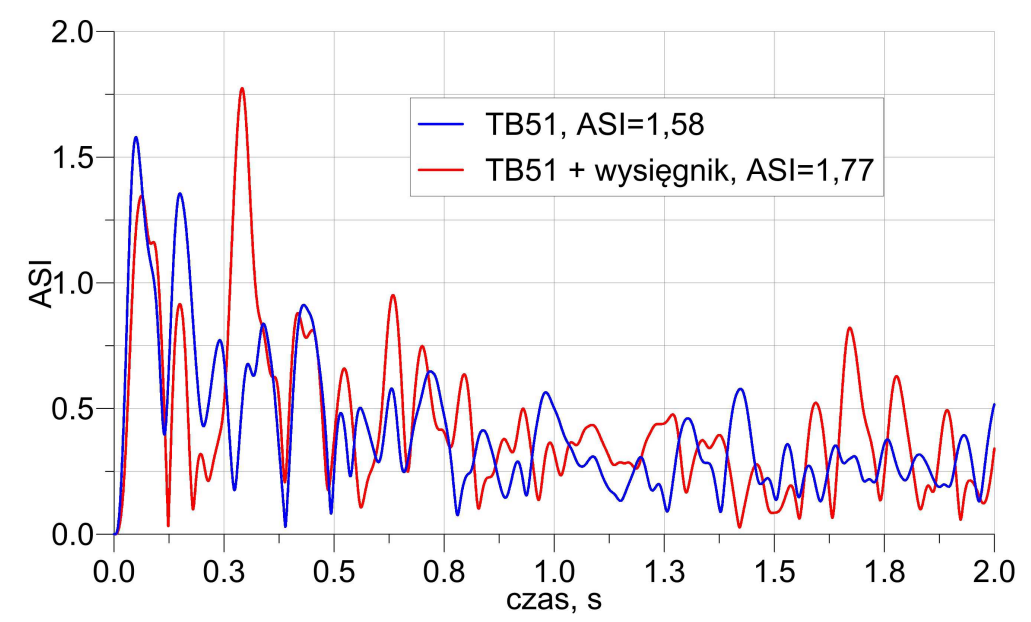

Rys. 9. Przebieg czasowy współczynnika ASI uzyskany w symulacjach numerycznych

Fig. 9. ASI curves in numerical simulations

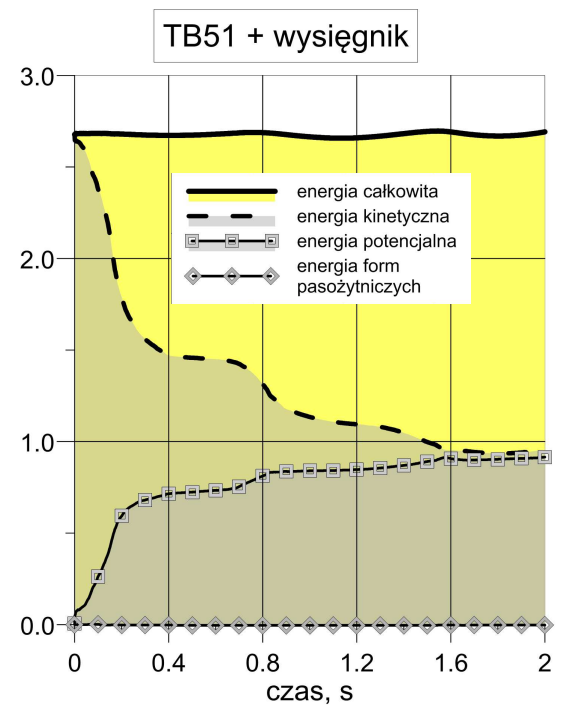

Rys. 10. Bilans energii w układzie dynamicznym w trakcie symulacji dla testu TB51 z wysięgnikiem

Fig. 10. Energy balance in a dynamic system during the simulation of test TB51 with supporting structure 


\section{Uwagi końcowe}

Drogowe urządzenia bezpieczeństwa ruchu pełnią bardzo ważną rolę w procesie poprawy stanu BRD w Polsce. Metodykę sprawdzania konieczności zastosowania barier ochronnych $\mathrm{w}$ zależności od zagrożeń występujących na drodze lub w jej otoczeniu, parametrów ruchu drogowego, klasy drogi, a także sposób ustalania cech funkcjonalnych barier ochronnych i sposób ich usytuowania na drodze, zawarto w wytycznych ich stosowania. Jednakże wytyczne te nie spełniają wszystkich oczekiwań projektantów i wykonawców barier, a także administracji drogowej. Dlatego konieczne jest kontynuowanie badań w celu aktualizacji tych wytycznych. Użytecznym narzędziem w badaniach zderzeń pojazdów $\mathrm{z}$ urządzeniami BRD są symulacje numeryczne. W pracy przedstawiono wybrany przypadek zderzenia autobusu $\mathrm{z}$ barierą mostową oraz uderzenia w system bariera mostowa i urządzenie wsporcze. Wyniki analiz numerycznych wskazują na znaczący udział konstrukcji wsporczej w zderzeniu, która powoduje istotne zmiany w trwałych odkształceniach bariery dla obu badanych konfiguracji zderzenia. Uwzględnienie konstrukcji wsporczej wpływa także na parametr ASI zwiększając jego wartość o $12 \%$.

\section{Podziękowania}

Praca wykonana w ramach projektu Urzadzenia bezpieczeństwa ruchu drogowego" (nr umowy DZP/RID-I-67/13/NCBR/2016). Obliczenia wykonano na komputerach Centrum Informatycznego Trójmiejskiej Akademickiej Sieci Komputerowej.

\section{Literatura}

[1] Budzyński M., Jamroz K.: Roadside Trees as a Road Safety Hazard in Poland. TRB AFB(20) 2 Meeting on Road Side Safety Design - 5 November 2014, Brussel.

[2] Budzyński M., Jamroz K., Jeliński Ł., Antoniuk M., Wilde K.: Otoczenie drogi źródłem zagrożeń dla uczestników ruchu drogowego. Drogownictwo, R. 70, nr 4-5 (2015), s. 126-133.

[3] Budzyński M., Jamroz K.: Strategia zmniejszenia liczby i skutków wypadnięcia pojazdu z drogi. Drogownictwo, R. 64, nr 4-5 (2009), s. 134-142.

[4] Lee J., Mannering F.: Research Assistant Professor and Chair Analysis of roadside accident frequency and severity and roadside safety management. Final Research Report Research Project T9903, Task 97, Analysis of Roadside Accident Severity \& Roadside Safety Management; U.S. Department of Transportation, Federal Highway Administration, Washington 1999.

[5] Jamieson N.J., Waibl G., Davies R.: Use of roadside barriers versus clear zones. NZ Transport Agency research report 517, Wellington, New Zealand, 2011.

[6] Holdridge J. M., Shankar V. N., Ulfarsson G. F.: The crash severity impacts of fixed roadside objects. Journal of Safety Research 36 (2005) 139-147.

[7] GDDKiA: Wytyczne stosowania drogowych barier ochronnych na drogach krajowych. GDDKiA Warszawa, 2010. 
[8] PE-EN 1317-1/8, Systemy ograniczające drogę - Część 1-8. Polska Norma (części przygotowane i w trakcie przygotowania).

[9] Wytyczne stosowania drogowych barier ochronnych na drogach krajowych, Załącznik do Zarządzenia Nr 31 Generalnego Dyrektora Dróg Krajowych i Autostrad z dnia 23.04.2010, Warszawa, 2010.

[12] Ren Z., Vesenjak M., Computational and experimental crash analysis of the road safety barrier, Engineering Failure Analysis, 12 (2005) 963-973.

[13] Borovinsek M., Vesenjak M., Ulbin M., Ren Z., Simulation of crash test for high containment levels of road safety barriers, Engineering Failure Analysis, 14 (2007) 1711-1718.

[14] Barnas A., Edl T.: Heavy Impact on Bridge Restraint Systems - State of Art - Loading Cases and analysis - Advantages of Modern Bridge Restraint Systems. International Conference on Bridges, Dubrownik, Croatia 2006.

[15] Thai H.: Performance evaluation of steel and composite bridge safety barriers by vehicles crash simulation , Interaction and Multiscale Mechanics, vol. 3, No 4 (2010) 405-414.

[16] Atahan A., Cansiz O.: Impact analysis of vertical flared back bridge rail-to-guardial transition structure using simulation. Finite Elements in Analysis Design, 41 (2005) 371-396.

[17] Livermore Software Technology Corporation, 7374 Las Positas Road, Livermore, CA 94551, www.lstc.com \{dostęp 15.05.2016 r.\}.

[18] http://www.vikorsta.com/Products/Traffic-safety/Bridge-parapets/Orsta-bridge-parapet/ \{dostęp 15.05.2016 r.\}.

[19] Determination of Structural Capacity by Non-linear FE analysis Methods, DET NORSKE VERITAS AS, 2013.

\section{NUMERICAL SIMULATIONS OF BUS CRASH-TEST WITH BARRIER AND TRUSS SUPPORTING STRUCTURE}

\section{S u m m a r y}

The paper presents initial results concerning numerical simulations of crash tests where the bus impacts the bridge parapet safety barrier and additional obstacle in the form of the truss supporting structure placed in the working width of the barrier. Such accident is one of the most popular albeit dangerous event. Here the characteristics of the so-called hard road neighbourhood are presented along with some possibilities of mitigating the risk. Numerical results of the crash tests are presented.

Keywords: road safety devices, numerical simulations, crash tests, road neighbourhood, Finite Element Method

Przestano do redakcji: 07.06.2016 $r$.

Przyjęto do druku: 30.06.2016 r.

DOI: 10.7862/rb.2016.54 